Мок Лафлин; пер. с англ. - М.: Дело, 1999. $208 \mathrm{c}$.

20. Мочалина, О.С. Развитие инновационно-инвестиционного процесса как фактор реализации инновационного потенциала [Электронный ресурс] / О.С. Мочалина // Ефективна економіка: електронне наукове фахове видання. - 2014. №7. Режим доступу:

www.economy.nayka.com.ua/?op=1\&z=3183

21. Основи інвестиційно-інноваційної діяльності [Текст]: навчальний посібник / За наук. ред. В.Г. Федоренко. - К.: Алеута, 2004. $431 \mathrm{c}$.

22. Плішка, Т.П. Інноваційноінвестиційні процеси в регіоні [Текст] / Т.П. Плішка // Університетські наукові записки. - 2009. - №3(31). - С. 364-368.

23. Про інвестиційну діяльність [Електронний ресурс]: закон України: [офіц. текст: станом на 06.11.2014]. - Режим доступу: http://zakon5.rada.gov.ua/laws/main/1560-12

24. Про інноваційну діяльність [Електронний ресурс]: закон України: [офіц. текст: станом на 05.12.2012]. - Режим доступу: http://zakon5.rada.gov.ua/laws/show/40-15

25. Философия: энциклопедический словарь [Текст] / Под ред. А.А. Ивина. - М.: Гардарики, 2006. - 1072 с.

26. Філіппов, М.І. Аналіз інноваційноінвестиційної діяльності підприємств легкої промисловості [Текст] / M.I. Філіппов, Т.Б. Гаврищук // Вісник КНУТД. - 2013. - 3. C. $132-138$.
27. Черваньов, Д.М. Менеджмент інноваційно-інвестиційного розвитку підприємств в Україні [Текст] / Д.М. Черваньов, Л.І. Нейкова. - К.: Знання, 1999. $516 \mathrm{c}$.

28. Шарп, У.Ф. Инвестиции [Текст] / У.Ф. Шарп, Г.Дж. Бэйли; пер. с англ. - М.: ИНФРА-М, 1997. - 1000 с.

29. Шастун, С.В. Інноваційноінвестиційна стратегія як інструмент формування конкурентних переваг підприємства [Електронний ресурс] / С.В. Шастун. - Режим доступу: http://eztuir.ztu.edu.ua/4832/1/111.pdf

30. Шумпетер, Й.А. Теория экономического развития [Электронный ресурс] / Й.А. Шумпетер. - М.: Прогресс, 1982. - 455 c. - Режим доступа: socio-line.ru/book/jshumpeter-teoriya-ekonomicheskogo-razvitiya

31. Экономико-математический словарь [Текст]: словарь современной экономической науки. - 5-е изд., перераб. и доп. - М.: Дело, 2003. $-520 \mathrm{c}$.

32. Яценко, О.В. Напрями розвитку інвестиційно-інноваційної діяльності підприємств [Текст] / О.В. Яценко // Збірник наукових праць ЧДТУ. - 2011. - №21. - С. 192197.

33. Mote, D. Encyclopedia of Business [Electronic resource] / D. Mote, K. Heil. $-2^{\text {nd }}$ ed. Access mode: http://www.referenceforbusiness.com/encyclopedi a/Inc-Int/Innovation.html

Рецензент д.е.н., професор УкрДУЗТ Зайцева І.Ю. Експерт редакційної колегії к.е.н., дочент УкрДУЗТ Зубенко В.О.

УДК 330.322

\title{
ФАКТОРИ ВПЛИВУ НА ГРОШОВИЙ ПОТІК В СФЕРІ ІНВЕСТИЦІЙНОЇ ДІЯЛЬНОСТІ
}

\author{
Щербань О. Д., к.е.н., доцент (ХІФ УДУФМТ)
}

У статті висвітлено проблему формування необхідної потреби у використанні грошових коштів підприємствами під впливом багатьох факторів різної сукупності. Зазначена залежність обсягу інвестичій від таких факторів: розподіл одержуваного доходу, очікувана норма прибутку, ставка позичкового відсотку, очікуваний темп інфляції. Доведена 
необхідність детального вивчення факторів, що зумовлюють формування позитивного $i$ від’ємного грошових потоків та здійснення їх аналізу при розробиі політики управління $i$ оптимізачї̈ грошових потоків підприємства та інвестиційної привабливості.

Ключові слова: інвестиційні вкладення, прибуток, фактори впливу, грошовий потік, грошовий оборот.

\title{
ФАКТОРЫ ВЛИЯНИЯ НА ДЕНЕЖНЫЙ ПОТОК В СФЕРЕ ИНВЕСТИЦИОННОЙ ДЕЯТЕЛЬНОСТИ
}

\author{
Щербань Е.Д., к.э.н., доцент (ХИФ УГУФМТ)
}

В статье рассматривается проблема формирования необходимой потребности в использовании денежных средств предприятиями под влиянием многих факторов разной совокупности. Указана зависимость объема инвестиций от таких факторов: распределение получаемого дохода, ожидаемая норма прибыли, проиентная ставка займа, ожидаемого темп инфлячии. Обоснована необходимость детального изучения факторов, влияющих на формирование положительного и отрицательного денежного потоков и проведение их анализа при разработке политики управления и оптимизации денежных потоков предприятия и инвестиционной привлекательности.

Ключевые слова: инвестиционные вложения, прибыль, факторы влияния, денежный поток, денежный оборот.

\section{THE INFLUENCE INTO THE INVESTMENTS OF THE ENTERPRISES}

\section{Shcherban O.D., Candidate of Economic Sciences, associate professor (KHIF UDUFMT)}

Investments are a basis of development of the entities, separate industries and national economies in general. Blossoming or self-produced decline, possibilities of the solution of social and environmental problems, modern level and potential dynamism of the physical, financial and human equities depends on ability to invest.

The investing activities are a wide complex of the purposeful, organizational, economic, financial, managerial works performed in interests of effective implementation of investments.

Forming of cash flows of the entity happens under the influence of simultaneous action various on the origin and nature of factors. Factors of external nature determine general terms of functioning of the entity. Factors of internal nature depend on specifics of activities of the entity. at the level of the entity of possibility of forming of a positive cash flow are characterized by the sphere of operating, investing and financial activities.

Treats the most important factors of external nature:

- a market situation of commodity, labor and material resources which determines the prices of their purchase, the tax and customs legislation which stipulates the sizes of an expenditure of money on tax payment, customs duties, other obligatory payments;

- the investment climate of the country which causes feasibility and amounts of investment investments of the entity;

- an environment of the financial market under the influence of which interest rates for bank loans, the necessary level of payment of share dividends of the entity are created.

The need for use of money is created under the influence of many factors which not always are managed from the entity. The cash flows connected with use of money by the sizes and rhythm, as a rule, don't match processes of forming of money as it is caused by influence of factors of various set.

Need of detailed studying of the factors causing forming of positive and negative cash flows and implementation of their analysis in case of development of policy of management and optimization of cash flows of the entity and investment appeal is proved.

Keywords: invstmens, profit, factors of influence, cash flow, cash turnover 
Постановка проблеми. Інвестиції $\epsilon$ основою розвитку підприємств, окремих галузей та економіки країни в цілому. Від уміння інвестувати, ефективно залучати фінансові ресурси, підвищувати інвестиційну привабливість підприємства залежить розквіт чи занепад власного виробництва, можливість вирішення соціальних й екологічних проблем, сучасний рівень i потенційний динамізм фізичного, фінансового та людського капіталів. Без надійних основ інвестиційної діяльності, якими б професійно володіли спеціалісти відповідного профілю, важко сподіватися на сталий розвиток вітчизняного виробництва, науково-технічний i соціальний прогрес, а 3 ними і на належне місце у світовому господарстві.

Аналіз останніх досліджень i публікацій. Проводячи аналіз публікацій 3 теми «Фактори впливу на інвестиційні вкладення підприємств» слід відмітити значне збільшення їх кількості в останні роки, що підтверджує актуальність обраної для дослідження теми. Серед авторів, що приділяли найбільшу увагу в своїх працях саме 3 цієї теми, відомі такі дослідники Бондар М. І. [1], Глущенко С. В. [2], Комарова А. I. [3], Пересада А. А., Зубленко В. В. [4], Ревуцька Н. П. [5], Савчук О. В. [6], Bruce А. Blonigen and Jeremy Piger [7].

Виділення невирішених частин загальної проблеми. Сьогодні як ніколи необхідні зусилля для пожвавлення господарчого життя 3 метою забезпечення стабілізації економіки й економічного зростання. Такого результату можна досягти на основі стабілізації, заохочення заощаджень та інвестицій, структурної перебудови, приватизації, створення ринку капіталів.

До невирішених питань щодо прийняття якісних управлінських рішень слід віднести ув'язування питань всебічного стійкого розвитку підприємства і його інвестиційної привабливості, а також формування комплексної, адекватної та загальноприйнятної системи оцінювання інвестиційної привабливості.

Метою статті $\epsilon$ визначення та аналіз впливу факторів на інвестиційні вкладення підприємств.

Виклад основного матеріалу дослідження. Інвестиції $є$ основою розвитку підприємств, окремих галузей та економіки країни в цілому. Від уміння інвестувати залежить розквіт чи занепад власного виробництва, можливість вирішення соціальних й екологічних проблем, сучасний рівень i потенційний динамізм фізичного, фінансового та людського капіталів. Без надійних основ інвестиційної діяльності, якими б професійно володіли спеціалісти відповідного профілю, важко сподіватися на сталий розвиток вітчизняного виробництва, науково-технічний і соціальний прогрес, а 3 ними і на належне місце у світовому господарстві.

Інвестиційна діяльність - це широкий комплекс цілеспрямованих проектних, організаційних, економічних, фінансових, управлінських робіт, що виконуються в інтересах ефективної реалізації інвестицій.

Джерелом приросту капіталу і метою інвестицій $\epsilon$ одержуваний від них прибуток (дохід). Перш за все, обсяг інвестицій залежить від розподілу одержуваного доходу на споживання i накопичення (заощадження). В умовах низьких доходів населення основна їх частка (75-80\%) витрачається на споживання. Зростання доходів громадян викликає підвищення частки, що направляється на заощадження, яке $є$ джерелом інвестиційних ресурсів. Отже, зростання частки заощаджень в загальному доході викликає збільшення обсягів інвестицій, і навпаки [6].

На обсяг інвестицій впливає очікувана норма прибутку, оскільки прибуток $\epsilon$ основним спонукаючим мотивом для них. Чим вище очікувана норма прибутку, тим більше обсяг інвестицій, і навпаки.

Істотний вплив на обсяг інвестицій має ставка позичкового відсотку, оскільки в процесі інвестування використовуються не тільки власні, але і позичкові засоби. Якщо норма очікуваного чистого прибутку виявляється вище за середню ставку позичкового відсотку, то такі вкладення вигідні для інвестора. Тому зростання процентної ставки викликає зниження обсягів інвестицій в економіку країни.

На обсяги інвестицій також впливає передбачуваний темп інфляції. Чим вище цей показник, тим більшою мірою 
знецінюватиметься майбутній прибуток інвестора і менше стимулів до збільшення обсягів інвестицій (особливо в процесі довгострокового інвестування). Тому в розробці бізнес-планів інвестиційних проектів вказані фактори повинні враховуватися при оцінці ефективності їх відбору для реалізації [3].

Формування грошових потоків підприємства загалом відбувається під впливом одночасної дії різних за своїм походженням і характером факторів.

Фактори, що визначають стан та структуру позитивного грошового потоку можливості формування позитивного грошового потоку є результатом сукупного впливу факторів зовнішнього та внутрішнього характеру, які формуються в сфері операційної, інвестиційної та фінансової діяльності підприємства.

Фактори зовнішнього характеру визначають загальні умови функціонування підприємства. До числа цих факторів належать загальна макроекономічна ситуація, стан та спрямованість законодавства, що регулює підприємницьку діяльність, стан платіжної дисципліни в державі, кон`юнктура ринка збуту, кон юнктура фінансового ринку тощо.

Ці фактори не залежать від діяльності окремого підприємства, але обумовлюють його потенційні можливості по формуванню грошових коштів. Чим сприятливіша макроекономічна ситуація, ліберальніше до підприємця господарське право та господарство, чим вищий попит на споживчому ринку, тим краща пропозиція на фінансовому ринку, тим кращі можливості підприємства щодо формування грошових коштів [2].

Фактори внутрішнього характеру залежать від характеру та специфіки діяльності самого підприємства. На рівні підприємства можливості формування позитивного грошового потоку та інвестиційних вкладень характеризується факторами:

1) сфери операційної діяльності;

2) сфери інвестиційної діяльності;

3) сфери фінансової діяльності.

Фактори, що впливають на позитивний грошовий потік в сфері операційної діяльності наведено на рис. 1.

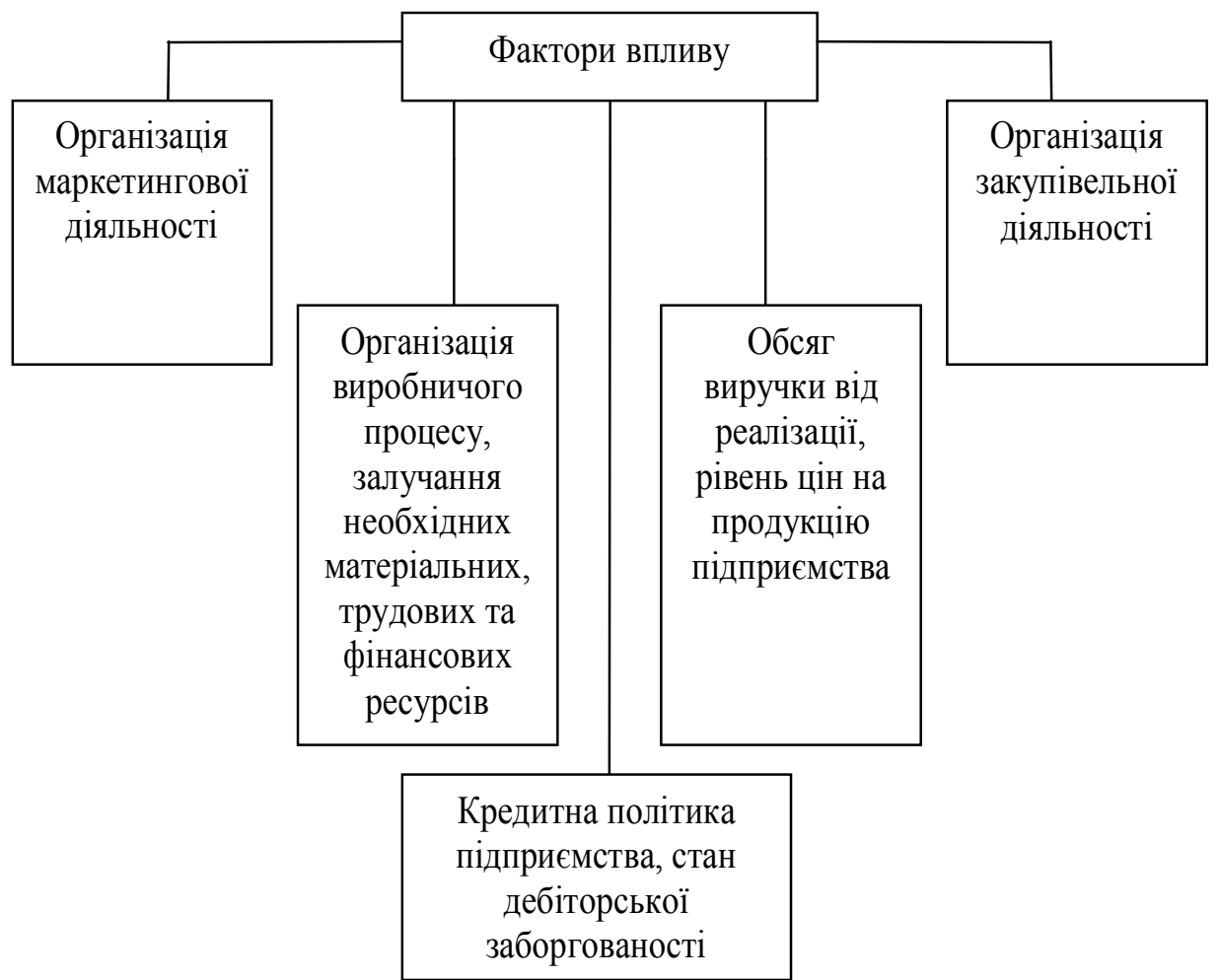

Рис. 1. Фактори впливу на позитивний грошовий потік в сфері операційної діяльності, розроблено за даними [1] 
Логіка впливу перелічених факторів на обсяги формування грошових коштів може бути визначена наступним чином: джерелом утворення грошей $є$ факт реалізації товарів, здійснення акту купівлі-продажу. На досягнення цього результату і повинна бути спрямована діяльність щодо управління факторами для максимізації находження грошових коштів [1].

В сфері фінансової діяльності:

$$
\text { - інвестиційна привабливість }
$$
підприємства для зовнішніх інвесторів, що визначає можливість ефективного розміщення додаткової емісії акції;

- кредитоспроможність підприємства щодо обслуговування зовнішніх боргів, що визначає можливість підприємства залучити банківські кредити;

- наявна структура капіталу, обсяг кредитів та позик, терміни їх повернення; підприємства.

- імідж та ділова репутація

Фактори впливу на позитивний потік грошових коштів в інвестиційній діяльності зображені на рис. 2.

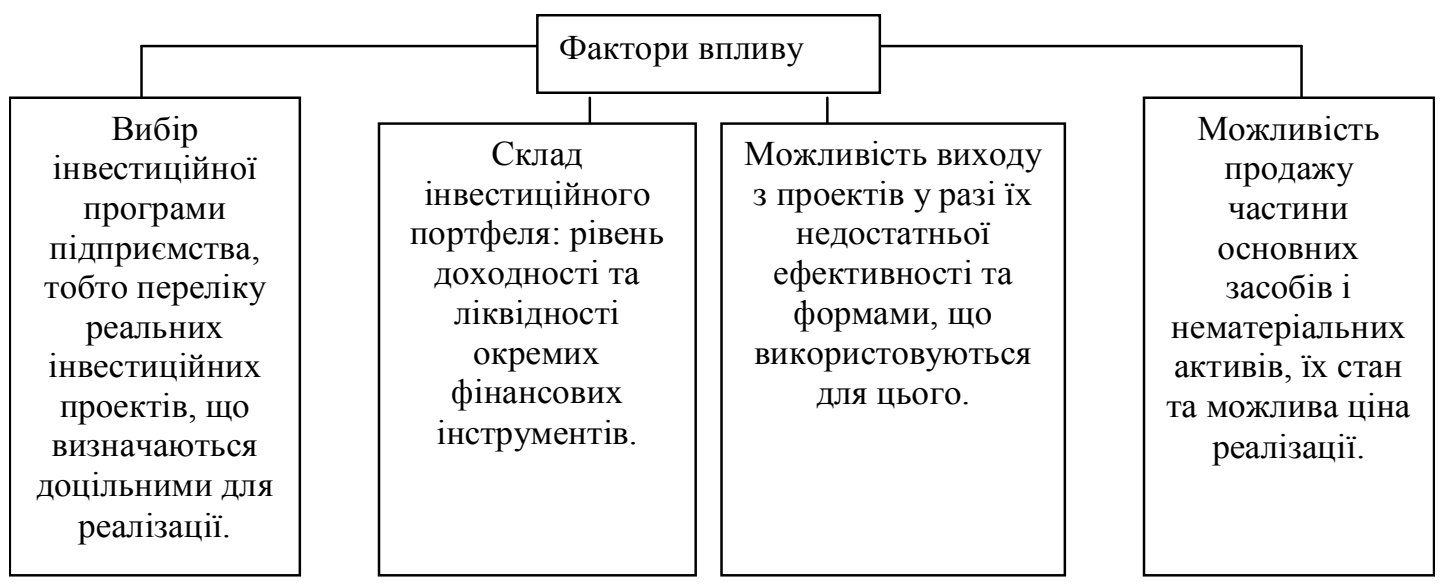

Рис. 2 Фактори впливу на позитивний грочовий потік в сфері інвестиційної діяльності розроблено за даними [5]

Фактори, що визначають обсяг та структуру від'ємного грошового потоку підприємства - потреба у використанні грошових коштів підприємства також залежить від факторів зовнішнього та внутрішнього характеру, проте їх перелік та напрям впливу має істотні особливості [5].

$$
\text { До найважливіших факторів }
$$
зовнішнього характеру належить:

- кон'юнктура ринків товарних, трудових та матеріальних ресурсів, яка визначає ціни їх закупівлі податкове та митне законодавство, яке обумовлюе розміри витрачання грошових коштів на сплату податків, митних зборів, інших обов'язкових платежів;
- інвестиційний клімат країни, який обумовлює доцільність та обсяги інвестиційних вкладень підприємства;

- кон'юнктура фінансового ринку, під впливом якої формуються процентні ставки за банківські кредити, необхідний рівень сплати дивідендів по акціям підприємства тощо.

Значно більшим чином потреба у використанні грошових коштів визначається впливом внутрішніх факторів, до складу яких в сфері операційної діяльності належать:

- обсяг постійних витрат та їх частка в загальному обсязі витрат підприємства;

- рівень змінних грошових витрат;

- ефективність закупівельної діяльності, проявом якої $є$ рівень цін закупівлі сировини (товарів) порівняно із середньо ринковим рівнем, система розрахунків з постачальниками; 
- чисельність персоналу підприємства, ефективність управління залученням, використанням та стимулюванням персоналу;

- обсяги та склад основних засобів підприємства, ïx вік, ремонтна політика підприємства;

- довжина операційного циклу та його окремих складових.

В сфері інвестиційної діяльності [4]:

- стратегічні цілі підприємства щодо темпів та напрямів розвитку;

- стан основних засобів та нематеріальних активів і необхідність ї оновлення;

- інвестиційна програма, загальний обсяг, терміни і графік освоєння;

- інвестиційний портфель підприємства.

В сфері фінансової діяльності:

- обсяг зовнішнього фінансування, терміни надання позик, необхідність їх фактичного погашення в певний період часу;

- склад співвласників (акціонерів) підприємства, їх стратегічні цілі та економічні інтереси;

- дивідендна політика підприємства, рівень та періодичність виплати дивідендів;

- доцільність викупу власних акцій та обмеження кількості акціонерів підприємства, ризик зниження вартості акціонерного капіталу в результаті їх продажу на вторинному ринку тощо.

Висновок. Потреба у використанні грошових коштів формується під впливом багатьох факторів, які не завжди є керованими 3 боку підприємства. Грошові потоки, пов'язані 3 використанням грошових коштів, за розмірами та ритмічністю, як правило, не співпадають 3 процесами формування грошових коштів, оскільки це обумовлюється впливом факторів різної сукупності. Розбалансування грошового обороту, неплатоспроможність підприємства має суттєве, навіть катастрофічне значення для підприємства, створюе загрозу виникнення ситуації банкрутства. Саме тому необхідне детальне вивчення факторів, що обумовлюють формування позитивного i від'ємного грошових потоків та їх аналіз при розробці політики управління та оптимізація грошових потоків підприємства та інвестиційної привабливості.

\section{СПИСОК ЛІТЕРАТУРИ}

1. Бондар М. І. Інвестиційна діяльність: методика та організація обліку i контролю / М. Бондар. - К.: КНЕУ, 2008. $280 \mathrm{c}$.

2. Глущенко С.В. Податкове стимулювання інвестицій у цінні папери /С. В. Глущенко // Фінанси України. — 2009. - № 1. - C. 70-74.

3. Комарова A.I. Регулювання інвестиційного розвитку України та міжнародний досвід / А. І. Комарова // Правосуддя - гарант у сфері економічно правових відносин. - 2010. -Том №21(1). - С. $147-151$.

4. Пересада А.А., Зубленко В.В. Реалізація інвестиційних проектів в Україні / А. А. Пересада, В. В. Зубленко // Фінанси України. - 2009. 一 №3. - C.106-109.

5.Ревуцька Н.П. Сучасні інструменти залучення іноземного капіталу / Н. П. Ревуцька // Цінні папери України. - 2010. - №9. - C.54-58.

6. Савчук О. В. Теорія і практика оцінки ефективності інвестицій в Україні /О.В.Савчук // Економіка України. - 2007. - № 12. - С.19-25.

7. Bruce A. Blonigen and Jeremy Piger. Determinants of foreign direct investment / Bruce A. Blonigen and Jeremy Piger // Canadian Journal of Economics Revue canadienne d'economique. 2014. - Volume 47, - Issue 3, - P.775-812.

Рецензент д.е.н., професор ХІФ УДУФМТ Матросова Л.М. Експерт редакційної колегії к.е.н., доцент УкрДУЗТ Зубенко В.О. 